\title{
Technical Note: Comparison of Techniques for Evaluating the Relative Preference by Sheep Among Saltbush Clones
}

\author{
Dario Giambalvo, Luigi Stringi, and Gaetano Amato
}

\author{
Authors are Professors, Dipartimento di Agronomia ambientale e territoriale, Università di Palermo, Palermo, Italy.
}

\begin{abstract}
This research compared 4 field methods of evaluating the relative preference by sheep of 28 clones of saltbush (Atriplex halimus L.). The methods were as follows. 1) Leaf dots (LD): 8 leaves per shrub were marked on the lower surface with a small dot using a water-resistant, nontoxic ink. 2) Twig marks (TM): 2 current-year twigs per shrub were marked with 3 lines using the same ink approximately in the middle of the basal, median, and apical thirds. 3) Branch length (BL): 2 branches per shrub were marked with ink at the base of the current year's growth. The twigs were measured from the marked point to the top, before and after sheep browsing. 4) Ocular estimation (OE): the percentage of the total number of current-year twigs browsed was visually estimated for each shrub. The percentage of use was calculated by counting the residual dots (LD) or marks (TM) after browsing and by calculating the difference between the 2 measures in the BL method. The trial was conducted in August and repeated in November and in both grazing periods 4 observations were made. Highly significant differences among clones were observed. The different methods generally gave similar results for the ranking of the clones, but each method showed a different discriminatory capacity. On the basis of the $F$ ratio, the $O E$ method seemed more efficient, although results were subjective and mainly dependent on the experience and skill of the observer. Among the methods based on the counting or measurement of markers, the discriminatory capacity decreased from LD to BL and TM, but the opposite order was observed for the ease of setting and counting the markers.
\end{abstract}

\section{Resumen}

Esta investigación comparó 4 métodos de campo para evaluar la preferencia relativa de los ovinos de 28 clones de "Saltbush" (Atriplex halimus L.). Los métodos evaluados fueron: 1) LD = Hojas con puntos: 8 hojas por arbusto se marcaron en la superficie baja con un pequeño punto usando tinta resistente al agua y no tóxica; 2) TM = Ramillas marcadas: En cada arbusto dos ramillas del crecimiento del año en curso se marcaron con 3 líneas usando la misma tinta del método anterior, las marcas se ubicaron aproximadamente en el centro de los tercios basal, medio y apical; 3) BL= Longitud de la rama: dos ramas por arbusto se marcaron con tinta en la base del crecimiento del año actual las ramas fueron medidas de los puntos marcados a la punta de ellas antes y después del ramoneo por los ovinos y 4) OE = Estimación ocular: En cada arbusto se estimó en forma visual el porcentaje total de ramillas del crecimiento del año en curso que fueron ramoneadas. El porcentaje de utilización fue calculado contando los puntos (LD) o marcas (TM) residuales después del ramoneo y calculando la diferencia entre las dos medidas en el método de BL. El ensayo se condujo en Agosto y se repitió en Noviembre y en ambos periodos de apacentamiento se hicieron 4 observaciones. Se detectaron diferencias altamente significativas entre clones. Los diferentes métodos generalmente produjeron resultados similares para clasificar los clones, pero cada método mostró diferente capacidad discriminatoria. En base a la relación de $\mathrm{F}$, el método OE pareció ser más eficiente, aunque, los resultados fueron subjetivos y principalmente dependientes de la experiencia y habilidad del observador. Entre los métodos basados en conteos o mediciones de las marcas, la capacidad discriminatoria disminuyó en el siguiente orden LD, BL y TM, pero el orden opuesto se observó en la facilidad de poner las marcas y contarlas.

Key Words: Atriplex halimus, forage shrubs, palatability

\section{Introduction}

Saltbush (Atriplex halimus L.) plantings are an effective way to rehabilitate degraded Mediterranean arid and semiarid lands because this shrub is able to grow under conditions of aridity and salinity; it can provide forage during dry seasons and periods of shortage of grazing resources (Le Houérou 1992). Its edible biomass has a high nutritive and digestibility value, but high content of sodium chloride and antinutritional factors may reduce its palatability and intake (Alicata et al 2002; El-Shatnawi and Turuk 2002; Abu-Zanat et al 2003). Among

Correspondence: Prof. Gaetano Amato, Dipartimento di Agronomia ambientale e territoriale, Università di Palermo, Palermo, Italy. Email: amato@unipa.it

Manuscript received 13 May 2003; manuscript accepted 17 May 2004. and within natural populations, a wide variability in grazing value (from unpalatable to excellent) has been observed (Le Houérou 1992, 2002; Delgado et al 1995). Therefore, to fully exploit the forage potential of the species it is necessary to select genotypes with high palatability.

Several methods have been proposed to evaluate the relative palatability of shrubs; some of them are carried out indoors (Gillet et al 1983; Kenney and Black 1984) and do not consider all of the factors influencing animal preference (edible biomass position, access for browsing, spread of leaves on the branches, etc).

To evaluate relative palatability under field conditions, methods based on the record of time spent eating a certain source by direct observation or automated photography system have been proposed (Arnold 1985; Hunt and Hay 1990). Other field methods estimate the differences between the edible biomass before and after a browsing period. Such methods 
are suitable for obtaining information about relative palatability as well as controlling the degree of use of a natural or artificial stand. The estimates are carried out using different types of measurements, such as ocular estimation, dimensions of the whole shrub, dimensions of particular reference units (eg, length and diameter of twigs; Jensen and Urness 1981), and number of marked leaves (microdot method; Lange 1984).

The field techniques for evaluating preference by animals, however, differ in ease of technique, cost effectiveness, objectivity, and discriminating capacity. The aim of this study was to compare different methods of screening saltbush clones for relative preference by sheep under field conditions. Since the chemical composition and digestibility of saltbush biomass show a wide variability in relation to physiological phase (Alicata et al 2002; El-Shatnawi and Turuk 2002), the comparison was carried out in 2 seasons: summer (August) and autumn (November).

\section{Materials and Methods}

\section{Environment}

The study was carried out at Pietranera farm, located about 30 $\mathrm{km}$ north of Agrigento in Italy (lat, $37^{\circ} 33^{\prime} \mathrm{N}$ long, $13^{\circ} 30^{\prime} \mathrm{E}$; mean altitude $200 \mathrm{~m}$ ) on a Vertic xerochrept soil with a mean slope of about $5 \%$.

Climate of the study area is semiarid Mediterranean with an average annual rainfall of $541 \mathrm{~mm}$ with $75 \%$ concentrated during autumn-winter and a dry period from May to September. Mean air temperatures are $15.9^{\circ}, 9.8^{\circ}, 16.5^{\circ}$, and $24.6^{\circ} \mathrm{C}$, respectively, in autumn, winter, spring, and summer.

\section{Plant Material and Experimental Design}

The experiment used 34 clones of saltbush derived from plants selected from 4 Sicilian populations (collected at Eraclea, Trapani, Butera, and S Biagio Platani). The mother plants were mainly chosen for size and leafiness, and the clones were previously investigated for forage production and regrowth capacity (Stringi et al 1994).

In September 1992, hardwood basal cuttings of the current year's growth were collected from the 34 selected mother plants. According to Amato et al (1990), the cuttings (8-10-cm length and $2-5-\mathrm{mm}$ diameter) were immediately treated with indole-3-butyric acid solution (IBA) at $2000 \mathrm{ppm}$, planted in plastic pots, and grown in an open-air nursery. In March 1993, the rooted cuttings were hand transplanted to a mould boardploughed and harrowed field in prepared holes with a $1.5 \times 1.5-\mathrm{m}$ spacing in a randomized block design with 10 replications (1 individual plant per clone per replication). The experimental field was surrounded by 2 border rows of plants belonging to the trial clones and randomly distributed; the field was then fenced in with a sheep-proof enclosure.

Plant mortality was $3.5 \%$ of the total transplanted cuttings irrespective of genotype; statistical analyses were performed only with data from the 28 clones that had viable plants in all 10 replications. Before the beginning of the browsing trials the field was hand weeded.

\section{Animals and Grazing Periods}

Twenty multiparous Comisana sheep with pretrial live weight of $42.8 \pm 1.28 \mathrm{~kg}$ were used; animals had eaten saltbush before. The browsing trials were carried out in August and November 1995 and lasted 16 and 12 days, respectively. All 20 animals were introduced in the paddock at once from 0800 to 1600 hours. During the grazing trials, animal diet was exclusively supported by shrub forage.

\section{Measurements, Calculation, and Statistical Analysis}

On each shrub, the edible biomass browsed was estimated using the following 4 methods:

1) Leaf dots (LD): 4 branches were randomly chosen and 2 leaves of each branch ( 8 leaves per shrub) were also randomly chosen and marked on the lower surface with a small dot (diameter about $3 \mathrm{~mm}$ ) using a water-resistant, nontoxic, yellow ink. Only living and animal-accessible leaves (external branches) were marked. To aid relocation, a yellow string was applied to the base of the branches with marked leaves. Lange (1984) showed that colored dots do not influence the grazing behavior of sheep. For each shrub, the percentage of use $(U)$ was computed as follows:

$U=[1-(\mathrm{DR} / 8)] \cdot 100$, where DR is the number of the dots counted after browsing.

2) Twig marks (TM): 2 branches were randomly chosen and 1 current year's twig of each branch was marked with 3 lines using a water-resistant, nontoxic, yellow ink. The lines were applied approximately to the middle of the basal, median, and apical thirds. For each shrub, the percentage of use $(U)$ was calculated as follows:

$U=[1-(\mathrm{DR} / 6)] \cdot 100$, where $\mathrm{DR}$ is the number of marks counted after browsing.

3) Branch length (BL): 2 branches per shrub were randomly chosen and marked with a dot using a water-resistant, nontoxic, yellow ink at the base of the current year's growth. The twigs were measured, from the marked point to the top, before and after sheep browsing. For each twig, the percentage of use $(U)$ was computed as follows:

$U=[1-(\mathrm{LR} / \mathrm{LT})] \cdot 100$, where LT and LR are the length of the twig before and after browsing, respectively. The percentage of use for each shrub was calculated averaging the values of the 2 twigs.

4) Ocular estimation (OE): the percentage of the total number of the current-year twigs browsed was visually estimated for each shrub by an observer.

All the methods were applied both in the August and November trials except BL method, which was only used in November. Aiming to identify the most appropriate time to estimate the relative preference during each of the grazing periods, 4 observations were carried out in both grazing periods at 4- and 3-day intervals in summer and in autumn, respectively. $\mathrm{OE}$ was done by a single observer for all the shrubs and sampling dates.

With the data from the 4 observations, for each clone a global index (GI) was calculated. In order to give equal importance to each observation, GI was not calculated as an arithmetical average of the 4 values but rather using the weighted average as follows: 


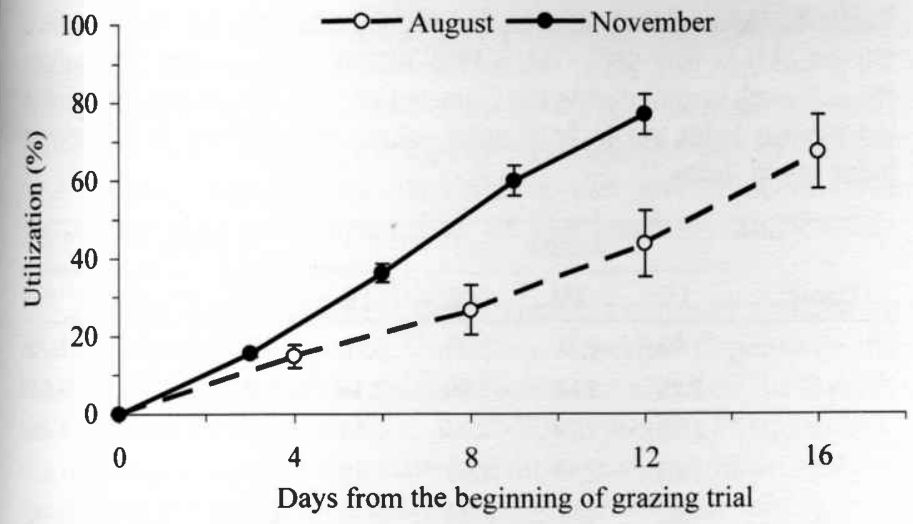

Figure 1. Edible biomass use (percentage of available edible biomass) during the August and November grazing trials. Values are mean of the methods studied ( $\pm 1 \mathrm{SE}$ ).

$$
\mathrm{GI}=\frac{\sum_{n=1}^{N}\left(x_{i n} / \bar{x}_{n}\right)}{N}
$$

where $N$ is the number of the observation, $x_{\text {in }}$ is the transformed value of $i$ th clone at the $n$th observation, and $\bar{x}_{n}$ is the average of all clones at the $n$th observation.

Before the beginning of the grazing trials, the edible plant biomass was estimated by hand removal of leaves and currentyear twigs from 28 shrubs ( 1 per each clone) chosen at random within the inner border row.

Percentage data were transformed in arcsine square root variable for analysis of variance. Analysis of variance was carried out separately for each method and observation.

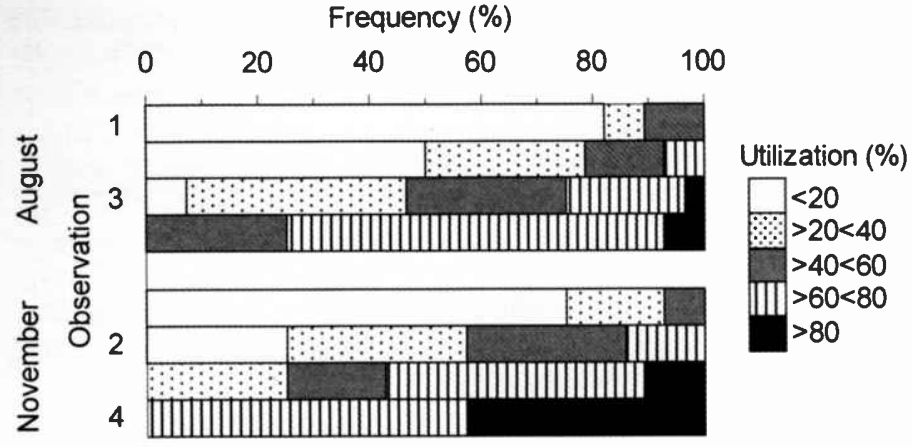

Figure 2. Frequency distribution of clones for the use of edible biomass (percentage of available edible biomass) at the 4 observations in the 2 grazing seasons. Frequencies were calculated on the basis of the mean values of biomass use of all the methods studied.

Treatment means were separated by the least significance difference (LSD) test if $F$ significant values $(P \leq 0.05)$ were obtained (Gomez and Gomez 1984).

\section{Results and Discussion}

The mean plant production was statistically similar in the 2 grazing seasons (average about $360 \mathrm{~g}$ of dry matter per plant). The trends of percentage use of edible saltbush biomass, calculated as an average of the 4 methods, are reported in Figure 1. Animals showed a faster use in November than in August, which may be related to the different animal feed needs associated with different physiological states (pregnant in

Table 1. Clone mean squares, error mean squares, and $F$ ratios for the methods studied $(\mathrm{LD}=$ leaf dots; $\mathrm{TM}=\mathrm{twig}$ marks; $0 \mathrm{E}=0 \mathrm{cular}$ estimation; $\mathrm{BL}=$ branch length) at each observation date (days from the beginning of the grazing trial) during the 2 grazing periods.

\begin{tabular}{|c|c|c|c|c|c|c|c|c|}
\hline \multirow[b]{2}{*}{ Methods } & \multicolumn{4}{|c|}{ August } & \multicolumn{4}{|c|}{ November } \\
\hline & Observation date & Clones $(27 \mathrm{df})^{1}$ & Error $(243 \mathrm{df})^{1}$ & $F_{\text {ratio }}{ }^{2}$ & Observation date & ${\text { Clones }(27 \mathrm{df})^{1}}^{1}$ & Error $(243 \mathrm{df})^{1}$ & $F$ ratio $^{2}$ \\
\hline LD & 4 & 1925.5 & 182.9 & 10.53 & 3 & 2249.1 & 203.0 & 11.08 \\
\hline TM & & 1147.9 & 152.9 & 7.51 & & 1300.0 & 212.5 & 6.12 \\
\hline $\mathrm{OE}$ & & 2072.8 & 124.8 & 16.60 & & 1379.1 & 100.8 & 13.69 \\
\hline$B L$ & & & & & & 1712.1 & 265.6 & 6.45 \\
\hline LD & 8 & 2804.2 & 222.5 & 12.60 & 6 & 3253.3 & 256.7 & 12.67 \\
\hline TM & & 1610.8 & 208.2 & 7.74 & & 1623.7 & 268.6 & 6.05 \\
\hline $\mathrm{OE}$ & & 3322.8 & 126.2 & 26.33 & & 2094.4 & 72.8 & 28.79 \\
\hline $\mathrm{BL}$ & & & & & & 2291.7 & 330.6 & 6.93 \\
\hline LD & 12 & 2219.4 & 242.1 & 9.17 & 9 & 2785.9 & 209.1 & 13.33 \\
\hline TM & & 1051.4 & 248.1 & 4.24 & & 1279.0 & 254.6 & 5.02 \\
\hline $\mathrm{OE}$ & & 2340.2 & 85.6 & 27.34 & & 1570.0 & 40.8 & 38.45 \\
\hline $\mathrm{BL}$ & & & & & & 1507.1 & 267.6 & 5.63 \\
\hline LD & 16 & 1287.2 & 179.0 & 7.19 & 12 & 937.1 & 138.7 & 6.76 \\
\hline TM & & 329.4 & 125.6 & 2.62 & & 619.1 & 260.9 & 2.37 \\
\hline $\mathrm{OE}$ & & 839.5 & 38.5 & 21.81 & & 994.7 & 40.2 & 24.74 \\
\hline$B L$ & & & & & & 547.5 & 203.0 & 2.70 \\
\hline LD & Global index & 2.04 & 0.14 & 14.85 & Global index & 1.64 & 0.09 & 17.50 \\
\hline TM & & 3.68 & 0.41 & 9.01 & & 1.41 & 0.17 & 8.26 \\
\hline $\mathrm{OE}$ & & 1.68 & 0.05 & 34.45 & & 1.30 & 0.04 & 33.53 \\
\hline $\mathrm{BL}$ & & & & & & 1.27 & 0.14 & 9.42 \\
\hline
\end{tabular}

${ }^{1} \mathrm{Df}=$ degree of freedom.

${ }^{2}$ Differences among clones were always significant for $P<0.001$. 
Table 2. Correlation coefficients between global indexes for the methods studied ( $L D=$ leaf dots; $T M=$ twig marks; $O E=$ ocular estimation; $\mathrm{BL}=$ branch length) during the 2 grazing periods.

\begin{tabular}{ccccccc}
\hline & \multicolumn{2}{c}{ August } & & \multicolumn{3}{c}{ November } \\
\cline { 2 - 3 } Method & LD & TM & & LD & TM & OE \\
\hline TM & 0.880 & & & 0.879 & & \\
OE & 0.969 & 0.887 & & 0.965 & 0.915 & \\
BL & - & - & & 0.890 & 0.994 & 0.932 \\
\hline
\end{tabular}

summer, lactating in autumn) and to the better nutritional and palatability characteristics of the autumn forage, due principally to the lower ash and sodium chloride contents (Alicata et al 2002).

The analysis of variance carried out separately for each method showed significant differences $(P<0.001)$ among the saltbush clones in every observation and in both browsing seasons (Table 1). This result confirmed the findings of Le Houérou (1992) about the variability for palatability within the species. However, the methods of evaluation showed a different discriminating capacity. In both browsing seasons, ocular estimation seemed the most efficient method since the $F$ ratio was greater than for the other methods in all observations and for the global index. The $F$ ratio of TM and BL methods were the lowest, whereas LD showed an intermediate screening capacity. The better performance of the ocular estimation method seemed mainly due to the lower experimental error.

Repeated observations during the browsing seasons showed that the 1 st and final observations (corresponding to a use of $10 \%-20 \%$ and of $60 \%-80 \%$ of the edible shrub biomass, respectively; Fig. 2) could be used to screen the most and the least palatable genotypes, respectively. The intermediate observations gave more detailed information about the relative preference of all genotypes.

A single observation, even in an intermediate stage of use, does not always seem to be adequate for a full classification, particularly if large variability exists among the accessions. In fact, in the evaluation of highly diversified material (different species or genotypes), the animal could browse the more palatable accession to its total exhaustion and then browse the next for preference and so on. Under these conditions a single observation could allow discrimination between used and nonused accessions, but not a full classification for relative palatability. On the contrary, repeated observations during the grazing trial, by weighing the degree of use and the rate of shrub use, are more likely to give a good classification of all the accessions.

In all observations, the methods studied generally gave a similar response on relative preference of saltbush clones (all correlation coefficients were significant at $P \leq 0.01$ ). The correlation coefficients between the different methods for the global index are reported in Table 2. Closer relationships between $\mathrm{LD}$ and $\mathrm{OE}$ methods and between TM and BL methods were observed. The methods studied were consistent in their ranking, but the LSD test allowed different discriminations among the clones (Table 3).

Most of the genotypes studied showed a high or very high stability of response for relative preference in the 2 browsing
Table 3. Mean global indexes for each clone and for each method studied (LD = leaf dots; TM = twig marks; OE = ocular estimation; $\mathrm{BL}=$ branch length) during the 2 grazing periods. Values not different to the highest index are in bold print; values not different to the lowest index are in italics.

\begin{tabular}{|c|c|c|c|c|c|c|c|}
\hline \multirow[b]{2}{*}{ Clones } & \multicolumn{3}{|c|}{ August } & \multicolumn{4}{|c|}{ November } \\
\hline & LD & TM & $O E$ & LD & TM & $O E$ & $B L$ \\
\hline 1 & 1.95 & 2.26 & 2.02 & 1.75 & 1.84 & 1.71 & 1.79 \\
\hline 6 & 2.19 & 2.69 & 1.99 & 2.13 & 1.68 & 1.87 & 1.64 \\
\hline 2 & 1.72 & 1.74 & 1.67 & 1.51 & 1.47 & 1.46 & 1.45 \\
\hline 3 & 1.65 & 2.11 & 1.58 & 1.42 & 1.34 & 1.41 & 1.39 \\
\hline 7 & 1.40 & 1.54 & 1.34 & 0.70 & 0.96 & 0.79 & 0.96 \\
\hline 29 & 1.25 & 1.51 & 1.28 & 1.01 & 0.99 & 1.12 & 1.01 \\
\hline 27 & 1.09 & 0.67 & 1.25 & 1.22 & 1.17 & 1.11 & 1.17 \\
\hline 28 & 1.25 & 1.27 & 1.19 & 1.03 & 1.19 & 1.13 & 1.20 \\
\hline 8 & 1.10 & 1.04 & 1.08 & 0.81 & 1.20 & 0.86 & 1.10 \\
\hline 5 & 1.20 & 1.39 & 1.06 & 1.21 & 1.37 & 1.14 & 1.30 \\
\hline 26 & 1.09 & 0.60 & 1.02 & 0.74 & 0.90 & 1.01 & 0.92 \\
\hline 4 & 0.74 & 0.91 & 0.99 & 1.43 & 1.46 & 1.53 & 1.48 \\
\hline 32 & 0.99 & 0.64 & 0.94 & 1.61 & 1.37 & 1.44 & 1.31 \\
\hline 36 & 0.97 & 0.70 & 0.85 & 1.08 & 0.70 & 1.02 & 0.76 \\
\hline 24 & 0.64 & 0.73 & 0.80 & 1.13 & 1.14 & 1.09 & 1.16 \\
\hline 23 & 0.83 & 0.44 & 0.79 & 0.93 & 0.98 & 1.01 & 0.97 \\
\hline 14 & 0.78 & 0.52 & 0.79 & 0.71 & 0.57 & 0.67 & 0.60 \\
\hline 31 & 0.87 & 1.10 & 0.76 & 0.73 & 0.96 & 0.87 & 0.98 \\
\hline 34 & 0.71 & 1.04 & 0.74 & 0.87 & 0.99 & 0.84 & 0.91 \\
\hline 13 & 0.74 & 0.65 & 0.74 & 0.52 & 0.54 & 0.54 & 0.56 \\
\hline 16 & 0.86 & 0.42 & 0.72 & 0.64 & 0.51 & 0.66 & 0.56 \\
\hline 12 & 0.71 & 0.52 & 0.73 & 0.55 & 0.77 & 0.71 & 0.76 \\
\hline 15 & 0.60 & 0.73 & 0.68 & 0.72 & 0.42 & 0.68 & 0.45 \\
\hline 25 & 0.73 & 0.55 & 0.67 & 0.72 & 0.66 & 0.64 & 0.68 \\
\hline 33 & 0.45 & 0.66 & 0.63 & 0.66 & 0.52 & 0.57 & 0.50 \\
\hline 21 & 0.69 & 0.49 & 0.62 & 0.85 & 0.96 & 0.74 & 1.00 \\
\hline 19 & 0.38 & 0.45 & 0.57 & 0.73 & 0.68 & 0.72 & 0.69 \\
\hline 20 & 0.41 & 0.60 & 0.49 & 0.58 & 0.65 & 0.65 & 0.69 \\
\hline \multicolumn{8}{|l|}{ L.S.D. } \\
\hline$(P=0.05)$ & 0.327 & 0.563 & 0.195 & 0.270 & 0.364 & 0.173 & 0.324 \\
\hline
\end{tabular}

seasons. However, for the global index, a significant browsing season by genotype interaction $(P \leq 0.05)$ was detected. More than $60 \%$ of the variability was dependent on the response of 4 clones (numbers 4, 7, 32, and 24). Further investigations are needed to identify the causes of such variability of response, and particular attention should be paid to regrowth capacity and morphostructural modifications caused by use.

\section{Conclusions}

Measurement made on the entire experimental unit (ie, the shrub, $O E$ method) was more discriminating for relative palatability than methods using a reference unit applied to a part of the shrub. It is also faster and easier and does not require particular preparation of the experimental unit (plant or population); however, the method is subjective and mainly dependent on the skill and experience of the observer. 
